\title{
Cluster analysis on Chinese university students' conceptions of English language learning and their online self-regulation
}

\author{
Jing Tao \\ University of International Business and Economics; Beijing University of Posts and \\ Telecommunications
}

Chunping Zheng

Beijing University of Posts and Telecommunications

\author{
Zhihong Lu \\ Beijing University of Posts and Telecommunications
}

\author{
Jyh-Chong Liang \\ National Taiwan Normal University \\ Chin-Chung Tsai \\ National Taiwan Normal University
}

This study investigated learners' conceptions of learning English and their online selfregulation in a web-based learning environment among. Two questionnaires, Conceptions of Learning English (COLE) and Online Self-regulation of English Learning (OSEL) were administered to 843 university students in China. Based on their different conceptions of learning English, participants were clustered into four groups. Two groups of students considered the process of learning English as understanding and seeing in a new way or being test-oriented. Another two groups consisted of students with high commitment to or low engagement in learning English. The results of ANOVA analysis and Scheffé's test revealed significant differences among the profiled participants in four groups. Students who considered learning English as understanding and seeing in a new way tended to have the strongest online self-regulatory competence. However, students who were test-oriented reported poorly in all aspects of online self-regulation. Our findings echoed previous studies on the relationship between conceptions of learning English and online self-regulation, particularly the negative association between learners' test-oriented conceptions of learning English and their online self-regulation. This research enables us to better understand English language learners in China, particularly in the era of information technology.

Implications for practice or policy:

- The research provided illuminating insights into four groups of learners about their conceptions of learning English and online self-regulation.

- More challenging learning tasks should be assigned to students with high commitment and more interest-arousing learning tasks to students with low engagement.

- Teachers should guide learners who view learning English as seeing in a new way and being test-oriented, to balance their internal interests in learning English with concern about achieving success in examinations.

Keywords: conception of learning; conceptions of English language learning; self-regulation; online self-regulation; cluster analysis

\section{Introduction}

Conceptions of learning refer to an individual's understanding of, or beliefs about learning and are considered as a critical variable for predicting students' learning approaches (Chiou, Liang, \& Tsai, 2012; Huang, Liang, \& Tsai, 2018), learning process (Lee, Johanson, \& Tsai, 2008; Sadi \& Lee, 2015; Vermunt \& Vermettan, 2004), and even learning outcomes (Peterson, Brown, \& Irving, 2010; Pinto, Bigozzi, Vettori, \& Vezzani, 2018). In order to understand the relationship between students' conceptions of learning and other variables, a number of qualitative and quantitative studies have been conducted among various student 
groups in different academic domains (Chiou et al., 2012; Sadi \& Dagyar, 2015; Vezzani, Vettori, \& Pinto, 2018).

Substantial investigations have been carried out for categorising learners' conceptions of learning (Chiou et al., 2012; Huang et al., 2018; Li, Liang, \& Tsai 2013). In the context of second language acquisition, conceptions of language learning are regarded as learners' beliefs about what a foreign language is and what the learning process consists of (Benson \& Lor, 1999). A series of studies have explored learners' conceptions of language learning and their relations to other variables, such as their language proficiency (Bagherzadeh \& Azizi, 2012; Peacock, 1999; Tanaka \& Ellis, 2003) and learning strategy use (Alhaisoni, 2012; Tang \& Tian, 2015). Researchers have also contended that students' conceptions of learning are one of the essential factors explaining their differences in online self-regulation (Li, Zheng, Liang, Zhang, \& Tsai, 2018; Zheng, Liang, Yang, \&Tsai, 2016).

Learners' self-regulation refers to their ability to control themselves while trying to achieve specific goals during the learning process (Zimmerman, 2000). The significance of self-regulation in traditional and blended learning environments has been shown by a considerable number of previous studies (Artino, 2007; Barnard, Lan, To, Paton, \& Lai, 2009; Broadbent, 2017; Moos \& Ringdal, 2012; Paris \& Paris, 2001). In the digital age, the Internet-based learning environment gives learners more freedom to participate in the learning process and also requires them to employ a plethora of online learning strategies (e.g., Cho \& Shen, 2013; Wandler \& Imbriale, 2017). Although previous studies have reported learners' conceptions of learning in general (Asikainen, Virtanen, Parpala, \& Lindblom-Ylänne, 2013; Purdie \& Hattie, 2002) or their conceptions of language learning specifically (Abedini, Rahimi, \& Zare-ee, 2011; Benson \& Lor, 1999), learners' various conceptions of learning in the domain of English language learning are still underexplored. Researchers are calling for more empirical studies, especially concerning different online selfregulated strategies employed by learners with different conceptions of language learning (Barnard, et al., 2009; Broadbent, 2017; Cho \& Shen, 2013). Therefore, this study aims to reveal the specific profiles of Chinese students' conceptions of English language learning by means of cluster analysis, and to understand how these distinct profiles relate to their strategies of online self-regulation.

\section{Literature review}

\section{Conceptions of learning and conceptions of language learning}

Conceptions of learning refer to learners' beliefs and views about "their learning experiences and ways of learning" (Liang \& Tsai, 2010, p. 2275). There are various studies that have explored conceptions of learning in general (Entwistle \& Peterson, 2004; Vermunt \& Vermetten, 2004) and in specific domains, such as science (Liang \& Tsai, 2010; Lin, Tsai, \& Liang, 2012), engineering (Ellis, Goodyear, Calvo, \& Prosser, 2008; Lin \& Tsai, 2009), biology (Chiou et al., 2012; Sadi \& Dagyar, 2015), chemistry (Li et al., 2013), accounting (Abhayawansa \& Fonseca, 2010; Byrne \& Flood, 2004; Moilanen, 2017), and mass communication (Huang et al., 2018). As English becomes a global language, increasing attention has been paid to the studies of conceptions of English language learning and their possible influence on other factors, such as learner autonomy (Abdel Razeq, 2014; Jafari, Ketabi, \& Tavakoli, 2017), learners' language proficiency (Abedini et al., 2011; Peacock, 1999; Tanaka \& Ellis, 2003), and use of learning strategies (Ayatollahi, Rasekh, \& Tavakoli, 2012; Dahl, Bals, \& Turi 2005).

Conceptions of learning were initially investigated and categorised by Säljö (1979). Based on interviews with 90 college students, Säljö (1979) identified five different types of conceptions of learning which perceived learning as: (1) an increase in knowledge, (2) memorising, (3) the acquisition of knowledge for retention or use in practice, (4) understanding, and (5) an interpretative process aimed at the understanding of reality. Following Säljö's study, Tsai (2004) proposed a framework for the conceptions of learning science, and revealed seven categories: (1) memorising, (2) preparing for tests, (3) calculating and practicing tutorial problems, (4) the increase of knowledge, (5) applying, (6) understanding, and (7) seeing in a new way. A number of follow-up studies have identified learners' conceptions of learning in domaindependent contexts. For instance, Li et al. (2013) divided conceptions of learning science into lower level conceptions (memorising testing, and calculating and practicing) and higher level conceptions (increasing one's knowledge, applying, understanding, and seeing in a new way). Zheng et al. (2016) adapted the conceptions of learning science and categorised conceptions of learning English in the field of second language acquisition. According to our categorization (Zheng et al., 2016), conceptions of learning English 
has seven factors: (1) memorising, (2) testing, (3) drill and practice, (4) grammar, vocabulary and pronunciation, (5) increasing one's knowledge, (6) application and communication, and (7) understanding and seeing in a new way. This typology has further been applied and validated among college students in mainland China (Luan \& Zheng, 2017) and in Korea (Cho, 2018). Although these studies revealed intricate relationships among the seven factors, studies on the interplay between learners' conceptions of language learning and their learning behaviors are still limited. More related explorations of learners' conceptions of language learning and their self-regulation in blended learning environments are expected in the future.

\section{Self-regulated learning and online self-regulated learning}

Self-regulated learning refers to students' ability to control themselves while trying to achieve specific goals during the learning process, and consists of many strategies including goal setting, self-efficacy, goal orientation, metacognitive monitoring, and self-evaluation (Panadero, 2017; Zimmerman, 2008). Selfregulated learning plays a vital role in classroom practices (Moos \& Ringdal, 2012; Paris \& Paris, 2001; Zimmerman, 2011). In the field of language learning, studies have investigated the potential interactions between self-regulated learning and language gains, such as vocabulary acquisition (Tseng, Dörnyei, \& Schmitt, 2006), writing (Teng \& Zhang, 2018), reading comprehension (Al Asmari \& Ismail, 2012), and listening proficiency (Vandergrift \& Goh, 2012; Yabukoshi, 2018). Compared with conventional classroom-based learning contexts, online learning requires learners to be more active in participating in online activities, and more responsible for self-managing and monitoring their learning process (Kuo, Walker, Schroder, \& Belland, 2014; Tsai, Ho, Liang, \& Lin, 2011). Therefore, learners need to have a stronger ability to self-regulate.

In recent years, a growing number of studies have investigated self-regulated learning in online environments (Tsai, Shen, \& Fan, 2013; Zheng, Liang, Li, \& Tsai, 2018; Zheng et al., 2016). In order to measure learners' abilities to self-regulate and monitor their learning in online and blended learning environments, Barnard et al. (2009) developed the Online Self-regulated Learning Questionnaire (OSLQ). Their instrument revealed six indicators of learners' online self-regulation including goal setting, time management, environment structuring, help seeking, task strategies, and self-evaluation. Grounded in the previous studies, Zheng et al. (2016) evaluated learners' online self-regulated learning in the context of English language learning by modifying the statements in OSLQ, and further developed the questionnaire of Online Self-regulated English Learning (OSEL). The follow-up studies investigated the intricate relationship between online self-regulation and the related variables among English as foreign language (EFL) learners. For example, Zheng et al. (2018) examined English language learners' motivational selfsystem in an online learning environment, and the results showed that different dimensions of online language learning motivation might have an impact on learners' online self-regulatory efforts. Cho (2018) also investigated EFL learners' conceptions of language learning and their self-regulatory strategies in Korea.

\section{The relationship between conceptions of language learning and online self-regulated learning}

Previous studies have shown an increasing interest in the relations between learners' conceptions of learning and their self-regulated learning strategies or academic achievement (Savoji, Niusha, \& Boreiri, 2013). For example, Li et al. (2018) explored students' conceptions, self-regulation, and strategies of learning science in mainland China, and their findings revealed that learners' conceptions of learning were powerful predictors of their metacognitive self-regulation. Researchers have also investigated the interplay between conceptions of learning and self-regulatory skills in the field of language learning in both conventional (Tang \& Tian, 2015; Zare-ee, 2010) and online environments (Ayatollahi et al., 2012; Tang \& Tian, 2015; Zheng et al., 2016). Zheng et al. (2016) confirmed that learners' conceptions of language learning play an essential role throughout the online learning process. Moreover, the factor, understanding and seeing in a new way, was found to be the most influential factor promoting learners' online selfregulation, while testing (test-oriented) had a negative correlation with online self-regulation. However, few studies have explicitly investigated the connection between profiled language learners with different conceptions of language learning and their self-regulation strategies. The current study aims to categorise English language learners based on their conceptions of English language learning, and then reveal the significant differences of strategy use in terms of their online self-regulated learning. The corresponding research questions are: 
1. How many groups of profiled EFL learners can be identified based on learners' conceptions of English language learning?

2. What are the significant differences among the profiled EFL learners in terms of their online selfregulation?

\section{Method}

\section{Participants}

The participants comprised 843 second year students (550 males and 293 females, mean age $=19.28$, see Table 3 for details) at a university in northern China. All the participants had more than 6 years of English language learning experience before entering the university. In order to cultivate students' English proficiency, the compulsory course, College English, was designed with a blended teaching mode. The 16week course is comprised of face-to-face instruction in class (a weekly 2-hour lecture) and online selfregulated learning via a learning management system (after class). Students are required to pre-study before class and complete assignments designed by the instructors after class. They can access resources (e.g., reading materials, lecture slides, tutorial recordings, and discussion boards) through the online learning management system. Most of the participants in this study were majoring in telecommunications, computer science, and electronic engineering, and they were familiar with online learning environments based on their blended learning experience in previous semesters at the university. The following two instruments were administered together to the participants.

\section{Instruments}

Instrument 1: The Conceptions of Learning English Questionnaire (COLE)

The first questionnaire was developed by Zheng et al. (2016) for assessing Chinese college students' conceptions of learning English and was mainly based on the Conceptions of Learning Science (COLS) proposed by Tsai (2004) and Tsai and Kuo (2008). In the COLE questionnaire, a total of 30 items were divided into seven factors. We adopted a 5-point Likert scale with values ranging from 1 (strongly disagree) to 5 (strongly agree). After the exploratory factor analysis, seven factors were retained: memorising; testing (test-oriented); drill and practice; grammar, vocabulary and pronunciation; increasing one's knowledge; application and communication; and understanding and seeing in a new way. In educational research, a reliability coefficient which is over .60 is considered to be acceptable and reliable. The alpha coefficient of the questionnaire was.61-.92 for each factor (overall alpha $=.83$ ), indicating that the internal consistency was sufficient for statistical analysis.

The two factors of COLE adopted in the current study with a sample item are as follows:

1. Testing (test-oriented) (five items): measuring the participants' conception of getting higher scores to pass English examinations. Sample item: "If there were no tests, I would not learn English."

2. Understanding and seeing in a new way (eight items): measuring the participants' conception of achieving true understanding and getting a new perspective through learning English. Sample item: "Learning English helps me understand more about other cultures and societies."

Instrument 2: The Online Self-regulation of English Learning Questionnaire (OSEL)

The second questionnaire, the OSEL, was adapted from the measurement developed by Barnard et al. (2009). The original questionnaire, Online Self-regulated Learning Questionnaire (OSLQ), was designed to measure students' self-regulation in online and blended learning environments. By changing the statements to target online English language learners more specifically, Zheng et al. (2016) developed the OSEL to investigate Chinese college students' online self-regulated English language learning. The 21 items in the OSEL were measured with a 5-point Likert scale, from 1 (strongly disagree) to 5 (strongly agree). It was divided into five factors: goal setting; environment structuring; task strategies and time management; help seeking; and self-evaluation. The alpha coefficient of the OSEL questionnaire was .76 -.86 for each factor (overall alpha $=.91)$, indicating a high internal consistency and reliability.

A brief description of the five factors in the questionnaire is as follows:

1. Goal setting (five items): assessing the participants' ability of planning and prearranging the outcomes of learning English online. Sample item: "I set goals to help myself manage study time for my online English learning." 
2. Environment structuring (four items): assessing the participants' ability of finding proper places for learning English online. Sample item: "I find a comfortable place where I can conduct online self-regulated English language learning."

3. Task strategies and time management (five items): assessing the participants' ability of adopting appropriate strategies and arranging a flexible schedule for fulfilling online tasks of English language learning. Sample item: "I prepare my questions before learning instructional materials online."

4. Help seeking (five items): assessing the participants' ability of asking for help from peers, teachers or other resources for online English learning. Sample item: "I share my problems with my classmates online so we know what we are struggling with and how to solve our problems."

5. Self-evaluation (four items): assessing the participants' ability of self-appraisal of their own online English learning. Sample item: "I summarise my online English learning to examine my understanding of what I have learned."

\section{Data analysis}

The data analysis of this study was performed in three steps. First, an exploratory factor analysis (EFA) with varimax rotation was performed to clarify the structural validity of the COLE and OSEL questionnaires. Second, a $k$-mean clustering analysis was conducted to identify the groups of participants with distinct patterns of conceptions of language learning and one-way ANOVA was conducted to determine the difference between the groups in the factor of testing (test-oriented) and the factor of understanding and seeing in a new way. Finally, the clusters of students' online self-regulated English language learning between the factors were compared by one-way ANOVA with a Scheffé test, which further unveiled the connections between the students' conceptions of English language learning and their online self-regulation.

\section{Results}

\section{Exploratory factor analysis of the questionnaires}

The EFA analysis of the Conceptions of Learning English (COLE)

Table 1 presents the results of the EFA analysis of the Conceptions of Learning English (COLE) survey. The Kaiser-Meyer-Olkin (KMO) value (.88) and the result of the Bartlett's test $\left(\chi^{2}=5182.59, \mathrm{p}<0.001\right)$ suggested the suitability of conducting factor analysis on the surveyed responses.

Table 1

The EFA analysis of the Conceptions of Learning English (COLE) survey (N=843)

\begin{tabular}{|c|c|c|c|c|}
\hline 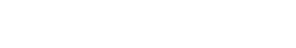 & \multirow[t]{2}{*}{ Item } & \multicolumn{2}{|c|}{ Factor loadings of COLE } & \multirow{2}{*}{$\begin{array}{c}\text { Cronbach's } \\
\alpha\end{array}$} \\
\hline & & Testing (test-oriented) & $\begin{array}{l}\text { Understanding and } \\
\text { seeing in a new way }\end{array}$ & \\
\hline \multirow{6}{*}{$\begin{array}{l}\text { Testing } \\
\text { (test-oriented) }\end{array}$} & $\mathrm{T} 1$ & 0.89 & & \\
\hline & T 2 & 0.88 & & \\
\hline & Т 3 & 0.84 & & 0.85 \\
\hline & T 4 & 0.83 & & \\
\hline & T 5 & 0.78 & & \\
\hline & Т 6 & 0.72 & & \\
\hline \multirow{5}{*}{$\begin{array}{l}\text { Understanding and } \\
\text { seeing in a new way }\end{array}$} & S 1 & & 0.88 & \\
\hline & S 2 & & 0.78 & \\
\hline & S 3 & & 0.78 & 0.91 \\
\hline & S 4 & & 0.75 & \\
\hline & S 5 & & 0.7 & \\
\hline
\end{tabular}

Note: Overall alpha $=0.67$

As revealed in previous studies, understanding and seeing in a new way showed strong positive prediction and was viewed as one of the higher-level conceptions, while testing (test-oriented) showed strong negative 
influence and perceived as one of the lower-level conceptions (Li et al., 2013; Tsai, 2004). In our study, these two factors were chosen as representative variables to investigate learner's conceptions of English language learning in mainland China. Thus, 11 items of the 2 factors of testing (test-oriented) and understanding and seeing in a new way were retained. The factor loading of testing (test-oriented) was between .72 and .89 , while understanding and seeing in a new way was between .70 and .88 . For the overall reliability, the Cronbach's alpha value was .67 . The alpha values of the two sub-scales were .85 and .91 . The results indicated the satisfactory level of construct validity and internal consistency of this modified questionnaire. Therefore, it is suitable to measure the university students' conceptions of learning English.

The EFA analysis of the Online Self-Regulated English Learning (OSEL)

The results of the exploratory factor analysis of the OSEL questionnaire are shown in Table 2. The KMO value (.91) and the result of the Bartlett's test $(\chi 2=8054.08, p<0.001)$ suggested the suitability of conducting factor analysis on the surveyed responses. Principal component analysis with varimax rotation was performed, and 22 items were grouped into five factors in the OSEL survey, that is, goal setting (GS), time management and task strategies (TSTM), environment structuring (ES), self-evaluation (SE), and help seeking (HS). The reliability (alpha) coefficient scores for each factor were .86, .82, .81, .82 and .75 and the overall alpha was .91 , which indicated a satisfactory level of internal consistency.

Table 2

The EFA analysis of the Online Self-regulated English Learning (OSEL) survey $(N=843)$

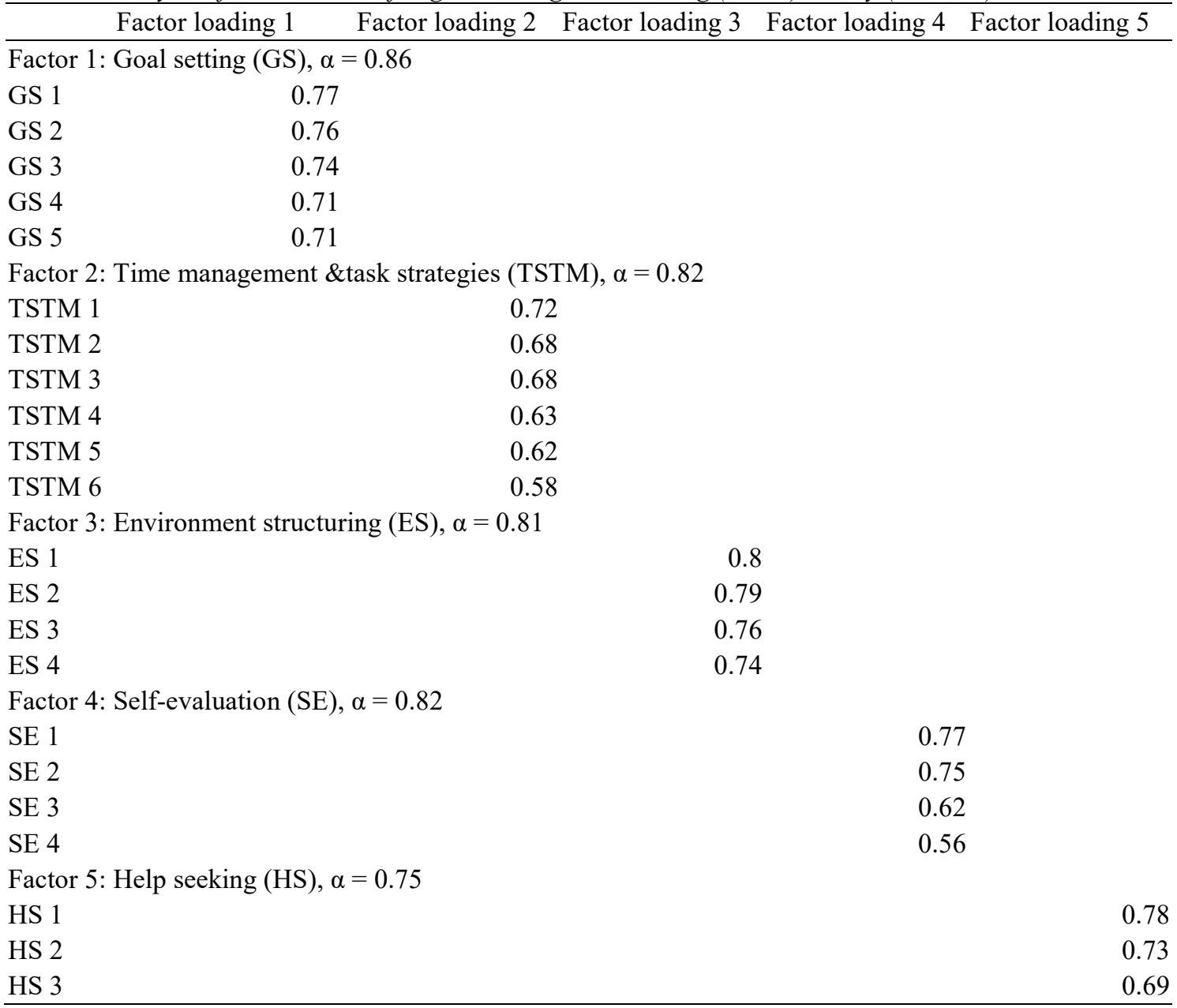

Note: Overall alpha $=0.91$

The clustered participants' Conceptions of Learning English (COLE)

Figure 1 showed the diagram of the four groups of clustered learners in the COLE survey. According to the diagram, the y-axis stands for the variable understanding and seeing in a new way, a typical factor of high 
conception of learning, while the x-axis for testing (test-oriented), a typical factor of low conception of learning. The results of $k$-mean cluster analysis revealed that our participants were clustered into four groups: Cluster 1 (seeing in a new way), Cluster 2 (being test-oriented), Cluster 3 (low engagement) and Cluster 4 (high commitment). As can be seen from the diagram, Cluster 1 (seeing in a new way) were inclined to the y-axis, and Cluster 2 (being test-oriented) were inclined to the x-axis separately. The other two clusters, Cluster 3 (low engagement) and Cluster 4 (high commitment) were between the coordinate axes. Compared with Cluster 3 (low engagement), Cluster 4 (high commitment) had relatively higher rate in the coordinate axes.

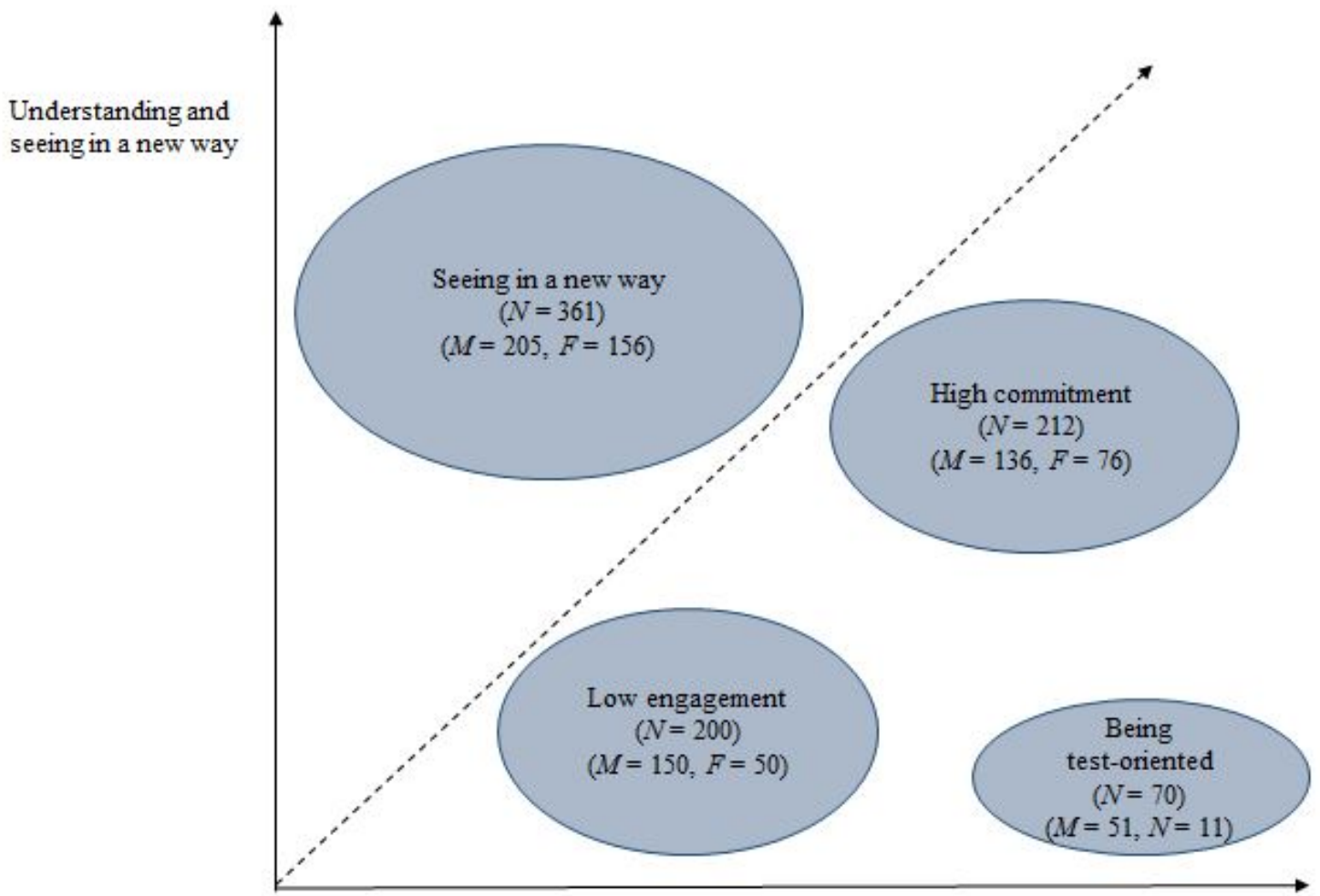

Testing

Figure 1. Diagram of the four groups of clustered learners (Please refer to Table 3 for details of variables)

As presented in Table 3, the clusters of learners differed significantly in their conceptions of understanding and seeing in a new way $(F=328.59, p<.001)$ and testing (test-oriented) $(F=682.83, p<.001)$. Scheffé test was used to further analyse the differences among the groups. Learners in Cluster 1 (seeing in a new way) showed highest score in their conception of understanding and seeing in a new way, while the lowest score in testing (test-oriented). These results suggested that students who perceived learning English as getting a new perspective instead of aiming for achievements in tests would express more agreement with learning English to broaden their horizons, and to achieve better understanding and more effective communication with others. On the contrary, students in Cluster 2 (being test-oriented) showed the opposite directions. They had the highest score in their conception of testing (test-oriented) and the lowest score in understanding and seeing in a new way. It indicated that learners in this group were mainly motivated by their performance in tests and examinations. Learners in Cluster 3 (low engagement) had relatively lower scores in the conception of testing (test-oriented) while their conception of understanding and seeing in a new way was statistically the same as learners in Cluster 2 (being test-oriented). A possible explanation was that these students made little effort on their study, and were reluctant to be involved in English language learning. By contrast, learners in Cluster 4 (high commitment) regarded obtaining higher scores (test-oriented) as being as important as broadening their outlook (understanding and seeing in a new way), thus they had relatively higher scores in both conceptions of learning English as understanding and seeing in a new way and testing (test-oriented). 
Table 3

ANOVA analysis of the clustered participants' conceptions of learning English (COLE)

\begin{tabular}{|c|c|c|c|c|c|c|}
\hline $\begin{array}{c}\text { Conceptions of } \\
\text { language learning } \\
\text { groups }\end{array}$ & $N$ & Male & Female & $\begin{array}{l}\text { Age range } \\
\text { Mean }(S D)\end{array}$ & $\begin{array}{l}\text { Understanding } \\
\text { and seeing in a } \\
\text { new way } \\
\text { Mean }(S D)\end{array}$ & $\begin{array}{c}\text { Testing (test- } \\
\text { oriented) } \\
\text { Mean }(S D)\end{array}$ \\
\hline (1) Seeing in a new way & 361 & 205 & 156 & $\begin{array}{r}14-22, \\
19.23(.80)\end{array}$ & $\begin{array}{l}4.29 \\
(.41)\end{array}$ & $\begin{array}{l}1.86, \\
(.41)\end{array}$ \\
\hline (2) Being test-oriented & 70 & 59 & 11 & $\begin{array}{r}18-21 \\
19.21(.81)\end{array}$ & $\begin{array}{l}3.13, \\
(.66)\end{array}$ & $\begin{array}{l}3.90, \\
(.46)\end{array}$ \\
\hline (3) Low engagement & 200 & 150 & 50 & $\begin{array}{r}17-22 \\
19.33(.72)\end{array}$ & $\begin{array}{l}3.27 \\
(.41)\end{array}$ & $\begin{array}{l}2.24, \\
(.41)\end{array}$ \\
\hline (4) High commitment & 212 & 136 & 76 & $\begin{array}{r}18-22, \\
19.34(.80)\end{array}$ & $\begin{array}{l}4.12, \\
(.40)\end{array}$ & $\begin{array}{l}3.02, \\
(.40)\end{array}$ \\
\hline$F$ (ANOVA) & & & & & $328.59^{* * *}$ & $682.83 * * *$ \\
\hline Scheffé test & & & & & $(1)>(4)>(3)=(2)$ & $(2)>(4)>(3)>(1)$ \\
\hline
\end{tabular}

$* * * p<.001$

Note: "=" in this table indicates no significant differences between group (3) and group (2) in

"Understanding and seeing in a new way" (mean difference $=1.40, p=0.15>0.05$ ).

The clustered participants' Online Self-Regulated English Learning (OSEL)

Table 4 depicts the mean values and standard deviations of the OSEL factors in each cluster and the comparisons of the post hoc tests. The results of the ANOVA analyses indicated that there were significant differences among clusters for goal setting $(F=22.61, p<0.001)$, environment structuring $(F=7.12, p<$ $0.001)$, time management and task strategies $(F=12.80, p<0.001)$, help seeking $(F=10.46, p<0.001)$, and self-evaluation $(F=17.21, p<0.001)$. Followed by a series of post hoc tests (Scheffé tests), it is evident that the four clusters could be employed to interpret the differences among the five online self-regulated learning factors.

As shown in Table 4, learners in Cluster 1 (seeing in a new way) reflected relatively the best performance in the process of online self-regulated English language learning. They rated their goal setting significantly higher than those in the groups of low engagement and being test-oriented $(M=3.55>3.22>2.96)$, and higher than those in the group of high commitment $(M=3.55>3.37)$. They also performed better on the scales of environment structuring $(M=3.98)$, time management and task strategies $(M=3.13)$, help seeking $(M=3.33)$ and self-evaluation $(M=3.56)$ than those in Cluster 2 (being test-oriented) and Cluster 3 (low engagement). Learners with the conception of English language learning as being test-oriented (Cluster 2) could be viewed as the most maladaptive cluster since learners in this group have the lowest scores in all the dimensions of OSEL. Learners within low engagement profile rated higher than those within being testoriented profile only in term of goal setting $(M=3.22>2.96)$. They showed significantly lower scores than the learners in the clusters of seeing in a new way and high commitment in all the other aspects. It is noticeable that learners with high commitment had higher scores than learners in the groups of being testoriented or low engagement in almost all dimensions of OSEL except environment structuring. Generally, it appeared that learners in the groups of seeing in a new way and high commitment had relatively adaptive self-regulated learning strategies, while those in the remaining two groups (being test-oriented and low engagement) had maladaptive characteristics. 
Table 4

ANOVA analysis of the clustered students' online self-regulation (OSEL)

\begin{tabular}{|c|c|c|c|c|c|}
\hline Cluster group & (Mean, $S D$ ) & $\begin{array}{l}\text { Environment } \\
\text { structuring }\end{array}$ & $\begin{array}{c}\text { Time } \\
\text { management } \\
\text { and task } \\
\text { strategies } \\
(\text { Mean, } S D)\end{array}$ & $\begin{array}{c}\text { Help } \\
\text { seeking }\end{array}$ & $\begin{array}{c}\text { Self- } \\
\text { evaluation }\end{array}$ \\
\hline (1) Seeing in a new & $(3.55,0.63)$ & $(3.98,0.55)$ & $(3.13,0.73)$ & $(3.33,0.73)$ & $(3.56,0.62)$ \\
\hline $\begin{array}{l}\text { way } \\
\text { (2) Being test- } \\
\text { oriented }\end{array}$ & $(2.96,0.78)$ & $(3.77,0.73)$ & $(2.69,0.74)$ & $(3.01,0.70)$ & $(3.09,0.74)$ \\
\hline $\begin{array}{l}\text { (3) Low } \\
\text { engagement }\end{array}$ & $(3.22,0.60)$ & $(3.77,0.58)$ & $(2.88,0.65)$ & $(3.15,0.66)$ & $(3.23,0.63)$ \\
\hline $\begin{array}{l}\text { (4) High } \\
\text { commitment }\end{array}$ & $(3.37,0.66)$ & $(3.86,0.60)$ & $(3.13,0.67)$ & $(3.44,0.66)$ & $(3.45,0.66)$ \\
\hline F (ANOVA) & $22.61 * * *$ & $7.12 * * *$ & $12.80 * * *$ & $10.46^{* * *}$ & $17.21 * * *$ \\
\hline Scheffé test & $(1)>(3)>(2)$ & $(1)>(2)$ & $(1)>(3)$ & $(1)>(2)$ & $(1)>(2)$ \\
\hline & $(1)>(4)>(2)$ & $(1)>(3)$ & $(4)>(2)$ & $(1)>(3)$ & $(1)>(3)$ \\
\hline & $(4)>(2)$ & & & $(4)>(2)$ & $(4)>(2)$ \\
\hline & & & & $(4)>(3)$ & $(4)>(3)$ \\
\hline
\end{tabular}

$* * * p<0.001$

Notes. (1) seeing in a new way $(N=361$, male $=205$, female $=156)$; (2) being test-oriented $(N=70$, male $=59$, female $=11)$; (3) low engagement $(N=200$, male $=150$, female $=50)$; (4) high commitment $(N=$ 212 , male $=136$, female $=76$ )

\section{Discussion}

The purpose of this study was to identify groups of EFL learners with different conceptions of language learning, and their online self-regulated learning. Here we highlighted two major findings from our data. First, the current study revealed four conceptions of language learning profiles, namely seeing in a new way, low engagement, being test-oriented, and high commitment. Second, we found that learners with different conceptions of English language learning showed significant differences in their strategy use in five factors of online self-regulation (i.e., goal setting, environment structuring, time management and task strategies, help seeking, and self-evaluation).

\section{Four profiles of learners' conceptions of English language learning}

In the current study, four clustered learner groups displayed distinctive differences in terms of their conceptions of English language learning. Learners in Cluster 1 (seeing in a new way) and Cluster 4 (high commitment) showed higher-level conceptions of English language learning, while learners in Cluster 2 (being test-oriented) and Cluster 3 (low engagement) tended to have lower-level conceptions of language learning. Previous work had empirically confirmed seeing in a new way as the most effective predictor for language acquisition (Cho, 2018; Zheng et al., 2016) while testing (test-oriented) was the most significant factor exerting negative effects on students' meaningful learning and intrinsic motivation (Liang \& Tsai, 2010). Therefore, our finding echoed the classification of higher-level and lower-level of conceptions of learning (Chiou et al., 2012; Tsai, 2004; Tsai et al., 2011). Another finding is that learners within the clusters of seeing in a new way and being test-oriented showed opposite attitudes towards the factors seeing in a new way and testing (test-oriented). Similarly, Gao et al. (2004) reported that learners with lower levels of intrinsic interest in the target language tended to focus on test scores, while those with higher levels of intrinsic interest were always less motivated to achieving high test scores. In the current study, learners with high commitment made great efforts to balance their interests and academic achievements, so they 
showed a strong sense of responsibility towards English language learning. On the contrary, learners with low engagement showed passive attitudes towards English language learning. Their reported scores on testing (test-oriented) and seeing in a new way were lower than the overall group, which indicated that they neither attached importance to broadening their horizons nor to succeeding in learning English. These two groups resembled the descriptions of the ambitious "eagle-like" students and sluggish "koala" students (Yu, Dai, Shao, \& Niu, 2016, p. 39), showing the two extreme types of English language learners.

\section{The significant differences among the profiled EFL learners in terms of their online self- regulation}

The current study re-emphasised Zheng et al.'s findings (2016) about the relationship between Chinese university students' conceptions of English language learning and their online self-regulation, and further revealed significant differences among the four profile-types in term of online self-regulated strategy use. Our results showed that learners in higher-level conception groups held significantly positive attitude toward the factors of OSRL. Learners in Cluster 1, seeing in a new way, showed great curiosity to the world through English language learning with clear learning goals, and learners with high commitment conducted online English language learning with definite purposes. The two groups of learners could optimise online English language learning effect through scientific arrangement of environment, time and adjust strategies to fulfill tasks. Learners with higher-level conceptions were adept in constructing their learning environment and seeking help. When they had obstacles in the learning process, they could ask for help from tutors, peers or even strangers via Internet. They also valued self-evaluation which could deepen their knowledge about the learning goals and effective learning strategies, monitor their progress, and decrease negative self-regulatory actions (Panadero \& Alonso-Tapia, 2013; Panadero, Jonsson, \& Botella, 2017). This finding echoed the importance of high-level conceptions of language learning on their online selfregulatory strategies (Chamot, 2018) and provided supports for the argument that learners in the groups of seeing in a new way and high commitment had greater positive perceptions of their online self-regulation (Tsai, 2004; Zheng et al., 2016). Characteristics were in accordance with the description of high engagement students by Lin, Deng, Hu and Tsai (2019). In contrast, the lower-level conceptions groups took a laissezfaire approach $(\mathrm{Xiao}, 2012)$ to construct online learning environment with ineffective time management and task strategies. In the cluster of being test-oriented, learners tended to view scores of the tests as the only criteria for academic achievement. Once they passed the test or achieved the goals, they would be less self-disciplined or self-motivated to carry on further study. Learners in the low engagement cluster seemed to be more reluctant to make efforts in the whole process of learning. Their online self-regulated behaviours were similar to the descriptions of passive students (Zimmerman, 2011) and unsuccessful students (Gerami \& Baighlou, 2011). For example, help-seeking was regarded as a critical self-control element of the performance phase of self-regulation in the online environment (Wandler \& Imbriale, 2017). In practical situation, low engagement learners took less time than learners in the group seeing in a new way. It verified that low-engagement learners had statistically lower scores in help-seeking $(M=3.15<3.33)$ than learners in the group of seeing in a new way.

\section{Conclusion}

The current study confirmed the interplay between conceptions of learning English and online selfregulation by clustering students in terms of their conceptions of learning English, and further investigating the differences among the profiled EFL learners in terms of their online self-regulation. Drawing upon our findings, we recommend that language instructors design adaptive and personalised instructions for different clustered groups of learners, in order to enhance their cross-cultural awareness and communicative competence. For learners with low engagement in learning English, teachers need to arouse their internal interest and promote their learner autonomy in learning a new language online, rather than overemphasising the significance of passing tests. For learners with high commitment to learning English, more challenging tasks should be designed to make their English language learning as a more adventurous, exploratory and enjoyable journey. For the groups where learning English was regarded as understanding and seeing in a new way or being test-oriented, teachers should guide learners to balance their intrinsic motivation to learn English with strong concern about achieving success in examinations. Additionally, peer influence could also help learners to take more initiative and be more engaged in the process of online English language learning. 
It is known that most Asian countries have been strongly influenced by a test-oriented culture (e.g., Berry, 2011; Lin, Liang, \& Tsai, 2015; Mee, 1998). For instance, in mainland China, College English Test (CET) certificates used to be the main criteria for measuring learners' academic achievement and English proficiency on and beyond the campus. However, in the last decade, there is an increasing trend for policymakers, researchers and teachers to reshape learners' conceptions of language learning from being testoriented to being more quality-oriented in language education (Wang, 2011; Wen, 2012; Xu \& Fan, 2016). Therefore, we believe our findings will have realistic implications in the foreseeable future.

This study has several limitations. First, we only investigated second year students at one university in the northern part of mainland China. Therefore, more participants from different age groups should be included to examine how age differences may affect learners' conceptions of learning English and their online selfregulation. Second, our study was largely based on self-reported data through two questionnaires. Due to the inherit limitations of this quantitative way of data collection, the statistically significant differences among clustered groups cannot fully predict or explain their differences in behaviours in reality. In order to overcome this weakness, we suggest that future research should employ more qualitative methods, such as in-depth interviews or analysis of the log files of learners' online learning, in order to explore their actual behavioural differences in online self-regulated learning. Finally, due to the dynamic nature of conceptions of learning, it is also advised to adopt a more dynamic and comprehensive perspective to explore EFL learners' beliefs in a blended learning environment.

\section{Acknowledgments}

We wish to express our gratitude to the anonymous reviewers and the editors for their precious comments. This research is funded by Fok Ying Tung Education Foundation (161093), the Fundamental Research Funds for the Central Universities (2019XD-A04), and the research project (2018TD04) supported by Beijing University of Posts and Telecommunications. Note: Liang, J.-C. and Tsai, C.-C. are currently affiliated with Institute for Research Excellence in Learning Sciences, National Taiwan Normal University.

\section{References}

Abdel Razeq, A. A. (2014). University EFL learners' perceptions of their autonomous learning responsibilities and abilities. RELC Journal: A Journal of Language Teaching and Research, 45(3), 321-336. https://doi.org/10.1177/0033688214547035

Abedini, A., Rahimi, A., \& Zare-ee, A. (2011). Relationship between Iranian EFL learners' beliefs about language learning, their language learning strategy use and their language proficiency. ProcediaSocial and Behavioral Sciences, Volume 28, 1029-1033. https://doi.org/10.1016/j.sbspro.2011.11.188

Abhayawansa, S., \& Fonseca, L. (2010). Conceptions of learning and approaches to learning-A phenomenographic study of a group of overseas accounting students from Sri Lanka. Accounting Education, 19(5), 527-550. https://doi.org/10.1080/09639284.2010.502651

Al Asmari, A. A., \& Ismail, N. M. (2012). Self-regulated learning strategies as predictors of reading comprehension among students of English as a foreign language. International Journal of Asian Social Science, 2(2), 178-201. Retrieved from http://www.aessweb.com/pdf-files/IJASS, 2(2), PP.178-201.pdf

Alhaisoni, E. (2012). Language learning strategy use of Saudi EFL students in an intensive English learning context. Asian Social Science, 8(13), 115-127. https://doi.org/10.5539/ass.v8n13p115

Artino, A. R. (2007). Self-regulated learning in online education: A review of the empirical literature. International Journal of Instructional Technology \& Distance Learning, 4(6), 3-18. Retrieved from http://www.itdl.org/Journal/Jun 07/article01.htm

Asikainen, H., Virtanen, V., Parpala, A., \& Lindblom-Ylänne, S. (2013). Understanding the variation in bioscience students' conceptions of learning in the 21 st century. International Journal of Educational Research, 62, 36-42. https://doi.org/10.1016/j.ijer.2013.06.010

Ayatollahi, M. A., Rasekh, A. E., \& Tavakoli, M. (2012). Learner beliefs, self-regulated learning strategies and 12 academic reading comprehension: A structural equation modeling analysis. World Applied Sciences Journal, 17(1), 36-49. Retrieved from http://www.idosi.org/wasj/wasj17(1)12/6.pdf

Bagherzadeh, H., \& Azizi, Z. (2012). Learners' beliefs about English language learning: examining the impact of English proficiency level on the motivation of students among non-English major EFL 
students. Theory and Practice in Language Studies, 2(10), 2096-2102.

https://doi.org/10.4304/tpls.2.10.2096-2102

Barnard, L., Lan, W. Y., To, Y. M., Paton, V. O., \& Lai, S. L. (2009). Measuring self-regulation in online and blended learning environments. The Internet and Higher Education, 12(1), 1-6. https://doi.org/10.1016/j.iheduc.2008.10.005

Benson, P., \& Lor, W. (1999). Conceptions of language and language learning. System, 27(4), 459-472. https://doi.org/10.1016/s0346-251x (99)00045-7

Berry, R. (2011). Assessment trends in Hong Kong: Seeking to establish formative assessment in an examination culture. Assessment in Education: Principles, Policy \& Practice, 18(2), 199-211. https://doi.org/10.1080/0969594X.2010.527701

Broadbent, J. (2017). Comparing online and blended learner's self-regulated learning strategies and academic performance. The Internet and Higher Education, 33, 24-32. https://doi.org/10.1016/j.iheduc.2017.01.004

Byrne, M., \& Flood, B. (2004). Exploring the conceptions of learning of accounting students. Accounting Education, 13(sup1), 25-37. https://doi.org/10.1080/0963928042000310779

Chamot, A. U. (2018). Developing self-regulated learning in the language classroom. In I. Walker, D. K. G. Chan, M. Nagami, \& C. Bourguignon (Eds.), New perspectives on the development of communicative and related competence in foreign language education (Vol. 28, pp. 41-52). Berlin, Boston: De Gruyter. https://doi.org/10.1515/9781501505034-003

Chiou, G. L., Liang, J. C., \& Tsai, C. C. (2012). Undergraduate students' conceptions of and approaches to learning in biology: A study of their structural models and gender differences. International Journal of Science Education, 34(2), 167-195. https://doi.org/10.1080/09500693.2011.558131

Cho, M. H., \& Shen, D. (2013). Self-regulation in online learning. Distance Education, 34(3), $290-301$. https://doi.org/10.1080/01587919.2013.835770

Cho, Y. A. (2018). Korean college students' conceptions of language learning and self-regulation in L2 acquisition. English Literature 21, 31(1), 255-276. Retrieved from https://www.earticle.net/Article/A326946

Dahl, T. I., Bals, M., \& Turi, A. L. (2005). Are students' beliefs about knowledge and learning associated with their reported use of learning strategies? British Journal of Educational Psychology, 75(2), 257273. https://doi.org/10.1348/000709905X25049

Ellis, R. A., Goodyear, P., Calvo, R. A., \& Prosser, M. (2008). Engineering students' conceptions of and approaches to learning through discussions in face-to-face and online contexts. Learning and Instruction, 18(3), 267-282. https://doi.org/10.1016/j.learninstruc.2007.06.001

Entwistle, N. J., \& Peterson, E. R. (2004). Conceptions of learning and knowledge in higher education: Relationships with study behavior and influences of learning environments. International Journal of Educational Research, 41(6), 407-428. https://doi.org/10.1016/j.ijer.2005.08.009

Gao, Y., Zhao, Y., Cheng, Y., \& Zhou, Y. (2004). Motivation types of Chinese university undergraduates. Asian Journal of English Language Teaching, 14, 45-6. https://doi.org/10.3969/j.issn.1003$\underline{6105.2003 .01 .005}$

Gerami, M. H., \& Baighlou, S. M. G. (2011). Language learning strategies used by successful and unsuccessful Iranian EFL students. Procedia-Social and Behavioral Sciences, 29, 1567-1576. https://doi.org/10.1016/j.sbspro.2011.11.399

Huang, W. L., Liang, J. C., \& Tsai, C. C. (2018). Exploring the relationship between university students' conceptions of and approaches to learning mass communication in Taiwan. The Asia-Pacific Education Researcher, 27(1), 43-54. https://doi.org/10.1007/s40299-017-0364-Z

Jafari, S., Ketabi, S., \& Tavakoli, M. (2017). Advanced and intermediate EFL learners' perceptions and practices of autonomous learning. International Journal of Applied Linguistics, 168(1), 70-90. https://doi.org/10.1075/itl.168.1.03jaf

Kuo, Y. C., Walker, A. E., Schroder, K. E., \& Belland, B. R. (2014). Interaction, Internet self-efficacy, and self-regulated learning as predictors of student satisfaction in online education courses. The Internet and Higher Education, 20, 35-50. https://doi.org/10.1016/j.iheduc.2013.10.001

Lee, M. H., Johanson, R. E., \& Tsai, C. C. (2008). Exploring Taiwanese high school students' conceptions of and approaches to learning science through a structural equation modeling analysis. Science Education, 92(2), 191-220. https://doi.org/10.1002/sce.20245

Li, M., Zheng, C., Liang, J. C., Zhang, Y., \& Tsai, C. C. (2018). Conceptions, self-regulation, and strategies of learning science among Chinese high school students. International Journal of Science and Mathematics Education, 16(1), 69-87. https://doi.org/10.1007/s10763-016-9766-2 
Li, W. T., Liang, J. C., \& Tsai, C. C. (2013). Relational analysis of college chemistry-major students' conceptions of and approaches to learning chemistry. Chemistry Education Research and Practice, 14(4), 555-565. https://doi.org/10.1039/C3RP00034F

Liang, J. C., \& Tsai, C. C. (2010). Relational analysis of college science-major students' epistemological beliefs toward science and conceptions of learning science. International Journal of Science Education, 32(17), 2273-2289. https://doi.org/10.1080/09500690903397796

Lin, C. C., \& Tsai, C. C. (2009). The relationships between students' conceptions of learning engineering and their preferences for classroom and laboratory learning environments. Journal of Engineering Education, 98(2), 193-204. https://doi.org/10.1002/j.2168-9830.2009.tb01017.x

Lin, C. L., Tsai, C. C., \& Liang, J. C. (2012). An investigation of two profiles within conceptions of learning science: an examination of confirmatory factor analysis. European Journal of Psychology of Education, 27(4), 499-521. https://doi.org/10.1007/s10212-011-0092-3

Lin, T. C., Liang, J. C., \& Tsai, C. C. (2015). Conceptions of memorizing and understanding in learning, and self-efficacy held by university biology majors. International Journal of Science Education, 37(3), 446-468. https://doi.org/10.1080/09500693.2014.992057

Lin, X. F., Deng, C., Hu, Q., \& Tsai, C. C. (2019). Chinese undergraduate students' perceptions of mobile learning: Conceptions, learning profiles, and approaches. Journal of Computer Assisted Learning, 35 (4), 317-333. https://doi.org/10.1111/jcal.12333

Luan, L. \& Zheng, C. (2017). The construction and application of an evaluation scale for assessing college students' conceptions of learning English. Modern Educational Journal, 27(9), 85-92. https://doi.org/10.3969/j.issn.1009-8097.2017.09.013

Mee, C. Y. (1998). The examination culture and its impact on literacy innovations: The case of Singapore. Language and Education, 12(3), 192-209. https://doi.org/10.1080/09500789808666748

Moilanen, S. (2017). The context-specific conceptions of learning in case-based accounting assignments, students' characteristics and performance. Accounting Education, 26(3), 191-212. https://doi.org/10.1080/09639284.2016.1274915

Moos, D. C., \& Ringdal, A. (2012). Self-regulated learning in the classroom: A literature review on the teacher's role. Education Research International, 2012, 1-15. https://doi.org/10.1155/2012/423284

Panadero, E. (2017). A review of self-regulated learning: six models and four directions for research. Frontiers in Psychology, 8(422), 1-28. https://doi.org/10.3389/fpsyg.2017.00422

Panadero, E., \& Alonso-Tapia, J. (2013). Self-assessment: Theoretical and practical connotations. When it happens, how is it acquired and what to do to develop it in our students. Electronic Journal of Research in Educational Psychology, 11(2), 551-576. http://dx.doi.org/10.14204/ejrep.30.12200

Panadero, E., Jonsson, A., \& Botella, J. (2017). Effects of self-assessment on self-regulated learning and self-efficacy: Four meta-analyses. Educational Research Review, 22, 74-98. https://doi.org/0.1016/j.edurev.2017.08.004

Paris, S. G., \& Paris, A. H. (2001). Classroom applications of research on self-regulated learning. Educational Psychologist, 36(2), 89-101. https://doi.org/10.1207/S15326985EP3602_4

Peacock, M. (1999). Beliefs about language learning and their relationship to proficiency. International Journal of Applied Linguistics, 9(2), 247-263. https://doi.org/10.1111/j.1473-4192.1999.tb00175.x

Peterson, E. R., Brown, G. T., \& Irving, S. E. (2010). Secondary school students' conceptions of learning and their relationship to achievement. Learning and Individual Differences, 20(3), 167-176. https://doi.org/10.1016/j.lcsi.2017.11.001

Pinto, G., Bigozzi, L., Vettori, G., \& Vezzani, C. (2018). The relationship between conceptions of learning and academic outcomes in middle school students according to gender differences. Learning, Culture and Social Interaction, 16, 45-54. http://dx.doi.org/10.1016/j.lcsi.2017.11.001

Purdie, N. M., \& Hattie, J. (2002). Assessing students' conceptions of learning. Australian Journal of Educational and Developmental Psychology, 2, 17-32. Retrieved from https://core.ac.uk/download/pdf/10881606.pdf

Sadi, Ö., \& Dagyar, M. (2015). High school students' epistemological beliefs, conceptions of learning, and self-efficacy for learning biology: A study of their structural models. Eurasia Journal of Mathematics, Science \& Technology Education, 11(5), 1061-1079. https://doi.org/10.12973/eurasia.2015.1375a

Sadi,Ö., \& Lee, M. H. (2015). The conceptions of learning science for science-mathematics groups and literature-mathematics groups in Turkey. Research in Science \& Technological Education, 33(2), 182196. https://doi.org/10.1080/02635143.2014.996543

Säljö, R. (1979). Learning about learning. Higher education, 8(4), 443-451. https://doi.org/10.1007/BF01680533 
Savoji, A. P., Niusha, B., \& Boreiri, L. (2013). Relationship between epistemological beliefs, selfregulated learning strategies and academic achievement. Procedia-Social and Behavioral Sciences, 84, 1160-1165. https://doi.org/10.1016/j.sbspro.2013.06.719

Tanaka, K., \& Ellis, R. (2003). Study abroad, language proficiency, and learner beliefs about language learning. The Research Journal of the Japan Association for Language Teaching, 25(1), 63-85. Retrieved from http://citeseerx.ist.psu.edu/viewdoc/download?doi=10.1.1.537.7087\&rep=rep1\&type=pdf

Tang, M., \& Tian, J. (2015). Associations between Chinese EFL graduate students' beliefs and language learning strategies. International Journal of Bilingual Education and Bilingualism, 18(2), 131-152. https://doi.org/10.1080/13670050.2014.882882

Teng, L. S., \& Zhang, L. J. (2018). Effects of motivational regulation strategies on writing performance: A mediation model of self-regulated learning of writing in English as a second/foreign language. Metacognition and Learning, 13(2), 213-240. https://doi.org/10.1007/s11409-017-9171-4

Tsai, C. C. (2004). Conceptions of learning science among high school students in Taiwan: A phenomenographic analysis. International Journal of Science Education, 26(14), 1733-1750. https://doi.org/10.1080/0950069042000230776

Tsai, C. C., Ho, H. N. J., Liang, J. C., \& Lin, H. M. (2011). Scientific epistemic beliefs, conceptions of learning science and self-efficacy of learning science among high school students. Learning and Instruction, 21(6), 757-769. https://doi.org/10.1016/j.learninstruc.2011.05.002

Tsai, C. C., \& Kuo, P. C. (2008). Cram school students' conceptions of learning and learning science in Taiwan. International Journal of Science Education, 30(3), 353-375. https://doi.org/10.1080/09500690701191425

Tsai, C. W., Shen, P. D., \& Fan, Y. T. (2013). Research trends in self-regulated learning research in online learning environments: a review of studies published in selected journals from 2003 to 2012. British Journal of Educational Technology, 44(5), 107-110. https://doi.org/10.1111/bjet.12017

Tseng, W. T., Dörnyei, Z., \& Schmitt, N. (2006). A new approach to assessing strategic learning: The case of self-regulation in vocabulary acquisition. Applied Linguistics, 27(1), 78-102. https://doi.org/10.1093/applin/ami046

Vandergrift, L., \& Goh, C. C. (2012). Teaching and learning second language listening: Metacognition in action. New York, NY: Routledge. https://doi.org/10.4324/9780203843376

Vermunt, J. D., \& Vermetten, Y. J. (2004). Patterns in student learning: Relationships between learning strategies, conceptions of learning, and learning orientations, Educational Psychology Review, 16(4), 359-384. https://doi.org/10.1007/s10648-004-0005-y

Vezzani, C., Vettori, G., \& Pinto, G. (2018). University students' conceptions of learning across multiple domains. European Journal of Psychology of Education, 33(4), 665-684. https://doi.org/10.1007/s10212-017-0349-6

Wandler, J. B., \& Imbriale, W. J. (2017). Promoting undergraduate student self-regulation in online learning environments. Online Learning, 21(2), 1-16. Retrieved from https://files.eric.ed.gov/fulltext/EJ1149360.pdf

Wang, S. (2011). Some thoughts on college English teaching in China. Foreign Language Learning Theory and Practice, 1, 1-5. Retrieved from http://en.cnki.com.cn/Article en/CJFDTotalGWJX201101003.htm

Wen, Q. (2012). Challenges and countermeasures of college English: From the perspective of curriculum theory. Foreign Language Teaching and Research, Volume 2, 283-292. https://doi.org/10.3969/j.issn.1009-6426.2014.09.012

Xiao, J. (2012). Successful and unsuccessful distance language learners: an "affective" perspective. Open Learning: The Journal of Open, Distance and e-Learning, 27(2), 121-136. https://doi.org/10.1080/02680513.2012.678611

$\mathrm{Xu}, \mathrm{J} .$, \& Fan, Y. (2016). The evolution of the college English curriculum in China (1985-2015): changes, trends and conflicts. Language Policy, 16(3), 267-289. https://doi.org/10.1007/s10993-0169407-1

Yabukoshi, T. (2018). Self-regulation and self-efficacy for the improvement of listening proficiency outside the classroom. The Language Learning Journal, 1-14. https://doi.org/10.1080/09571736.2018.1472626

Yu, H., Dai, X., Shao L., \& Niu, H. (2016). The comparison of learning between top creative college students and ordinary college students. Fudan Education Forum, 14(5), 39-44. https://doi.org/10.13397/j.cnki.fef.2016.05.007 
Zare-ee, A. (2010). Associations between university students' beliefs and their learning strategy use. Procedia-Social and Behavioral Sciences, 5, 882-886. https://doi.org/10.1016/j.sbspro.2010.07.203

Zheng, C., Liang, J. C., Li, M., \& Tsai, C. C. (2018). The relationship between English language learners' motivation and online self-regulation: A structural equation modelling approach. System, Volume 76, 144-157. https://doi.org/10.1016/j.system.2018.05.003

Zheng, C., Liang, J.-C., Yang, Y.-F., \& Tsai, C.-C. (2016). The relationship between Chinese university students' conceptions of language learning and their online self-regulation. System, Volume 57, 66-78. https://doi.org/10.1016/j.system.2016.01.005

Zimmerman, B. J. (2000). Attaining self-regulation: A social cognitive perspective. In M. Boekaerts, P. R. Pintrich, \& M. Zeidner (Eds.), Handbook of self-regulation (pp. 13-39). San Diego, CA: Academic Press. http://dx.doi.org/10.1016/B978-012109890-2/50031-7

Zimmerman, B. J. (2008). Investigating self-regulation and motivation: Historical background, methodological developments, and future prospects. American Educational Research Journal, 45(1), 166-183. https://doi.org/10.3102/0002831207312909

Zimmerman, B. J. (2011). Motivational sources and outcomes of self-regulated learning and performance. In B. J. Zimmerman, \& D. H. Schunk, (Eds.), Handbook of self-regulation of learning and performance (pp. 63-78). New York, NY: Routledge. https://doi.org/10.4324/9780203839010.ch4

Corresponding author: C. Zheng, zhengchunping@bupt.edu.cn

Copyright: Articles published in the Australasian Journal of Educational Technology (AJET) are available under Creative Commons Attribution Non-Commercial No Derivatives Licence (CC BY-NCND 4.0). Authors retain copyright in their work and grant AJET right of first publication under CC BYNC-ND 4.0.

Please cite as: Tao, J., Zheng, C., Lu, Z., Liang, J.-C., \& Tsai, C.-C. (2020). Cluster analysis on Chinese university students' conceptions of English language learning and their online self-regulation. Australasian Journal of Educational Technology, 36(2), 105-119. https://doi.org/10.14742/ajet.4844 